\title{
Contra el deber sagrado: evasión al servicio militar obligatorio en Cundinamarca (1902-1932)*
}

\section{Resumen}

El artículo estudia la política de reclutamiento militar en Cundinamarca en los años veinte del siglo anterior, argumentando que esta fue permanentemente cuestionada por amplios sectores de la población, al ser considerada como selectiva y discriminatoria. Para ello se identifican los imaginarios que empleó el Estado para promover el reclutamiento militar y los que animaron a los conscriptos a cuestionarlo. Además, se analizan algunas estrategias utilizadas por los conscriptos para evadir una disposición que contribuyó a reforzar las diferencias sociales durante el periodo de estudio. El artículo se apoya en fuentes diversas como la legislación oficial sobre el servicio militar, los informes sobre reclutamiento elaborados por los prefectos de las provincias del departamento y los reportes que sobre el tema aparecieron en la prensa de la época.

Palabras claves: Servicio militar obligatorio, Cundinamarca, conscriptos, evasión.

Referencia para citar este artículo: DÍAZ JARAMILLO, José Abelardo (2016). "Contra el deber sagrado: evasión al servicio militar obligatorio en Cundinamarca (1902-1932), en Anuario de Historia Regional y de las Fronteras. 21 (1). pp. 261-291.

José Abelardo Díaz Jaramillo: Candidato a Doctor en Historia (Universidad Nacional de Colombia). Licenciado en Ciencias Sociales (Universidad Pedagógica Nacional). Magíster en Historia (Universidad Nacional de Colombia). Docente de dedicación exclusiva de la UNIMETA, vinculado al Centro de Investigaciones Socio Jurídicas Jorge Eliecer Gaitán. Correo electrónico: jodiz16@yahoo.com.

*Artículo de investigación científica. 


\title{
Against the Sacred Duty: Eluding Mandatory Military Service in Cundinamarca (1902-1932)
}

\begin{abstract}
This article focuses on the analysis of the military recruitment policies in Cundinamarca between 1902 and 1932, highlighting their questioning by broad sectors of the population that consider them selective and discriminatory. The article identify the images employed by the State to promote military recruitment and the factors that encouraged draftees to question military service. Furthermore, this paper analyzes some strategies utilized by draftees to evade a provision that, in fact, reinforced social differences during the period of study. The article is supported in several sources such as official legislation about military service, recruitment reports completed by prefects at regional level, and the reports published by the press at that time.
\end{abstract}

Keywords: mandatory military service, Cundinamarca, draftees, elusion.

\section{Contra o dever sagrado: evasão do serviço militar obrigatório em Cundinamarca (1902-1932)}

\section{Resumo}

O artigo estuda a politica de recrutamento militar na Cundinamarca (Colombia) entre 1902 e 1932 e planteia que esta foi permanentemente questionada por amplos setores da população ao ser considerada como seletiva e discriminatória. Para isso se identificam os imaginários que o Estado empregou para promover o recrutamento militar e os que motivaram os recrutas a questioná-lo. Além disso, se analisam algumas estratégias utilizadas pelos recrutas para evitar uma disposição que contribuiu para reforçar as diferenças sociais durante o periodo de estudo. $O$ artigo se apoia em fontes diversas como a legislação oficial sobre o serviço militar, os informes sobre recrutamento elaborados pelos prefeitos das províncias do departamento e os relatórios sobre o tema que apareceram na imprensa da época.

Palavras-chave: serviço militar obrigatório, Cundinamarca, recrutas, evasão. 


\section{Introducción}

Con acierto se ha advertido que en Colombia “[...] el estudio del servicio militar desde una perspectiva histórica ha sido descuidado como un tema de análisis particular o tratado de forma tangencial". Al respecto, es evidente la carencia de investigaciones que den cuenta, desde una perspectiva sistemática, de las políticas de reclutamiento militar implementadas por el Estado durante la vida republicana. Se trata, desde luego, de una empresa intelectual compleja y a la vez necesaria para comprender una institución que ha sido objeto de permanente crítica y rechazo por parte de sectores de la vida pública nacional. No obstante, no se pretende aquí ofrecer una mirada de conjunto a esa práctica; el propósito es menor y consiste en aportar, a partir de una mirada regional, elementos de análisis para avanzar en el conocimiento del tema. En concreto, nos interesa reconstruir los imaginarios sociales que circularon en torno al servicio militar obligatorio en Cundinamarca en la década de 1920. Igualmente, identificar las razones advertidas por los conscriptos para evadirlo y los mecanismos empleados para hacerlo.

El análisis del reclutamiento militar en Cundinamarca durante el periodo indicado (que ocasionalmente se contrastará con lo sucedido en otros lugares del país), permitirá confirmar su carácter antidemocrático, toda vez que, como veremos, este afectó fundamentalmente a los sectores más desválidos de la sociedad, reforzando las diferencias entre los distintos grupos sociales. En ese orden de ideas, el escrito está estructurado en cinco partes: inicialmente, se hace un breve recuento de la legislación sobre el reclutamiento militar en el país en las primeras tres décadas del siglo XX; luego, se establece la relación entre la demanda de autoridad en Cundinamarca y el incremento del reclutamiento militar; a continuación, se identifican los imaginarios de la institucionalidad y de los sectores populares en torno a la conscripción; enseguida, se establecen algunas formas de reclutamiento y las estrategias de evasión empleadas por los llamados "conscriptos"; y finalmente, se establecen algunas conclusiones.

\section{El reclutamiento militar en Cundinamarca a comienzos del siglo $X X$}

En sus memorias publicadas en 1886, el suizo Ernst Rothlisberger describió la impresión que le produjo un hecho ocurrido en las calles de Bogotá:

De forma sombría se advierte siempre la perspectiva de la cercana explosión de una guerra civil; al caer la tarde los soldados marchan en formación por las calles de la ciudad y detienen a todo pobre diablo que cae incautamente en sus manos, respetando al que lleva sombrero de copa o va bien trajeado. La persona así capturada es puesta entre dos filas de bayonetas; la primera continua hasta haber reunido veinte, a menudo cuarenta o cincuenta, de estos infelices. De ese modo, amarrados a veces como reses destinadas al matadero, se les conduce al

\footnotetext{
${ }^{1}$ Rodríguez Hernández, Saúl. “¡Aquí comienza la excelencia! Apuntes sobre conscripción y democracia en la Colombia contemporánea”, en Torres del Río, César y Rodríguez Hernández, Saúl (eds.), De milicias reales a milicias contrainsurgentes. La institución militar en Colombia del siglo XVIII al XXI (Bogotá: Editorial Pontificia Universidad Javeriana, 2008), p. 54.
} 
cuartel, donde quedan presos y donde se les obliga a enrolarse para la guerra. Muy raramente logra librarse el individuo tan violentamente reclutado, y muchas personas influyentes no consiguen eximir del servicio militar a sus criados, a sus obreros, a sus choferes [...] Ocurre con harta frecuencia que los soldados se introducen en las casitas de los pobres habitantes de las afueras y sacan al hombre de la cama, dejando a la mujer y a los hijos en total desamparo².

Describía Rothlisberger ${ }^{3}$ una práctica común en el medio que se alimentaba de las reiteradas confrontaciones políticas, y que lejos de desaparecer con el fin del siglo XIX, se proyectó sobre la siguiente centuria, sin visos de transformación ${ }^{4}$. En efecto, y siguiendo a Charles Bergquist, al momento de estallar la Guerra de los Mil Días en 1899 y durante la misma, el Gobierno central se vio en la necesidad de reclutar a personas para sortear los enfrentamientos militares, reproduciendo lo que ya Rothlisberger había descrito algunos años atrás:

En tanto políticos de clase alta y los gamonales locales se enrolaban voluntariamente como oficiales, llevando a menudo con ellos a sus clientes y dependientes en calidad de soldados rasos, el gobierno, para llenar las filas de sus ejércitos, recurría a los sistemas reconocidos del reclutamiento forzoso de hombres de las clases bajas 5 .

\section{Y agrega:}

Tan pronto se inició la guerra el gobierno se movilizó con rapidez para aumentar el número de hombres en armas. Como en guerras civiles anteriores, el gobierno dependía en gran manera del reclutamiento de trabajadores para formar sus ejércitos. Para capturar -son palabras de un general- (buenos indios para el servicio de las armas), escuadrones de hombres armados descendían a las plazas de mercado, a las tiendas donde vendían bebidas alcohólicas y a otros sitios de reunión de los pueblos. Los trabajadores empleados por el gobierno, tales como los de las cuadrillas de peones camineros, eran blanco automático para la conscripción. En el campo se capturaba por grupos a los jornaleros, que eran atados y conducidos a la guerra sin recurso a procedimientos legales ni tiempo para arreglar sus asuntos ni para despedirse de sus familias. Una vez enganchados, los reclutas tenían escasas oportunidades de recuperar su libertad, a menos que desertaran o que sus patronos o señores pudiesen movilizar en su favor influencias especiales con el gobierno ${ }^{6}$.

\footnotetext{
${ }^{2}$ Rothlisberger, Ernst. El Dorado (Bogotá: Instituto Colombiano de Cultura, Bogotá, 1993), pp. 151 y 152.

${ }^{3}$ Podrían citarse otros testimonios similares al del Ernst Rothlisberger elaborados por escritores, novelistas y políticos del siglo XIX, en donde se describen las injusticias derivadas de la aplicación del reclutamiento en sectores sociales particularmente desvalidos. Por razones de espacio, se han obviado.

${ }^{4}$ Desde los primeros momentos de la república, el Estado colombiano legisló sobre el reclutamiento militar, buscando en gran medida que este no se aplicara de forma violenta y tuviese un carácter verdaderamente democrático. Sobre este asunto se puede consultar a: Martínez Garnica, Armando. Historia de la Guardia Colombiana (Bucaramanga: Universidad Industrial de Santander, 2012).

${ }^{5}$ Berquist, Charles. Café y conflicto en Colombia (1886-1910). La Guerra de los Mil Días, sus antecedentes y consecuencias (Medellín: El Áncora Editores, Medellín, 1999), p. 206.

${ }^{6}$ Ibid., p. 210.
} 
Una canción anónima que circuló en el contexto de la Guerra de los Mil Días, conocida con el nombre de El recluta, daba cuenta de los procedimientos y consecuencias que producía en la vida de los campesinos el reclutamiento forzoso. Algunas de sus estrofas son contundentes en la descripción de las implicaciones del reclutamiento:

$$
\begin{aligned}
& \text { En mis montañas vivía tranquilo } \\
& \text { bajo una choza de ancho palmar, } \\
& \text { vestía a mi esposa, vestía a mis hijos, } \\
& \text { con los producidos de un colmenar. } \\
& \text { Vino la guerra con sus horrores, } \\
& \text { y en noche oscura con un cordel } \\
& \text { fui maniatado por una turba, } \\
& \text { y conducido para un cuartel. } \\
& \text { Me dieron rifle con municiones, } \\
& \text { y un juramento me fue exigido } \\
& \text { de dar mi vida, de dar mi sangre } \\
& \text { por un gobierno que no he querido. } \\
& \text { Fui licenciado para volverme } \\
& \text { a la cabaña que fabriqué; } \\
& \text { tan solo escombros, ruina y miseria } \\
& \text { hallé en el sitio que tanto amé. } \\
& \text { Maldita guerra con sus banderas, } \\
& \text { con sus divisas de enemistad, } \\
& \text { con sus fusiles y sus cornetas, } \\
& \text { que solo luto y lágrimas dan }
\end{aligned}
$$

Las situaciones vividas por quien era reclutado, algunas advertidas en la canción, se siguieron registrando a pesar de que desde finales del siglo XIX el Estado prestó atención a lo que comenzó a denominarse, no ya "el reclutamiento" sino "el servicio militar obligatorio", sin tener que acudir a la coacción para llevarlo a cabo. A esto, es decir, a la historia del servicio militar obligatorio, un investigador lo asoció a un viacrucis inaudito ${ }^{8}$ queriendo destacar que el camino que debió recorrer el reclutamiento para convertirse en política de Estado, fue bastante accidentado.

Una de las primeras leyes que buscó organizar lo que se comenzaría a llamar "el servicio militar obligatorio", fue la Ley 167 de 1896. En ella se establecieron criterios como que todos los ciudadanos entre los veintiuno y los cuarenta años debían prestar el servicio en el Ejército activo, las reservas o las milicias, según el caso. Además, con ella se redujo a tres años el máximo de tiempo que por obligación debía pasar un ciudadano en tiempos de paz. Igualmente, estableció la política de sorteo, estipulando una suma de dinero que debía ser cancelada por aquel se saliera eximido 9 .

\footnotetext{
${ }^{7}$ Perico García, Jenaro. El maestro Luis A. Calvo (Bucaramanga: Editorial Salesiana, 1975), pp. 19 y 20.

${ }^{8}$ Atehortua Cruz, Adolfo León. Construcción del Ejercito Nacional en Colombia, 1907-1930. Reforma Militar y misiones extranjeras (Medellín: La Carreta Histórica, 2009).

9 “Ley 167 de 1896 que organiza el Servicio Militar Obligatorio", en Compilación de las disposiciones que reglamentan el servicio militar obligatorio (Bogotá: Imprenta Nacional, 1915). Es de resaltar que en
} 
Además se estableció que en tiempos de paz quedaban eximidos del servicio el mayor de los huérfanos de padre y madre, el hijo único cuyos padres vivan, pero pasen de sesenta años, el hijo mayor o yerno de viuda con familia a la cual mantiene, el hermano de quien esté en servicio o haya muerto en él, el casado en el primer año de su matrimonio. De igual manera, se definió a quienes quedaban exceptuados transitoriamente: los jóvenes que sigan una carrera profesional, hasta que termine el estudio, los que ejercen cargos de elección popular o desempeñen cargo público fijado por la Ley, los individuos cuya presencia sea considerada perniciosa.

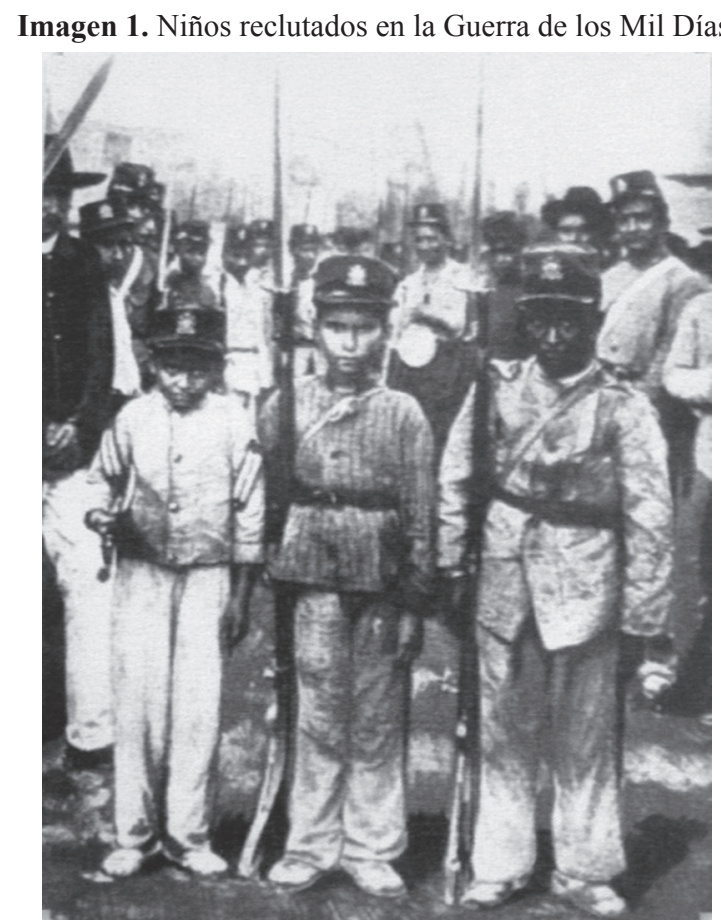

Fuente: Hernández Niño, Nicéforo. Evolución histórica del Servicio de Reclutamiento y Control Reservas del Ejército Nacional: 1810-2010 (Bogotá: Ejército Nacional, 2010), p.150.

No obstante, lo dispuesto en la Ley 167 de 1896 continuó registrando el sistema de reclutamiento forzoso de forma indiscriminada, lo cual dio pie para que desde las páginas de los periódicos se cuestionara dicha práctica, dando paso a un intenso cuestionamiento que dio resultados en 1909, cuando en el congreso se registró un sonoro debate en torno al reclutamiento, en el que el representante Adolfo León Gómez, jurista, escritor y poeta, asumió la posición de acabar con aquella bárbara costumbre, acogiendo el sentir de amplios sectores de la población colombiana. La prensa describió el ambiente suscitado en torno al debate del siguiente modo:

1882 se aprobó la Ley 20, con la cual se buscó avanzar en la prohibición del reclutamiento forzoso y la formación de destacamentos militares solo con voluntarios. Martínez Garnica, Armando. Historia de la Guardia Colombiana (Bucaramanga: Universidad Industrial de Cundinamarca, 2012), p. 66. 
La prueba de que tal proyecto, al realizarse, satisface un deseo general y vehemente de los Colombianos, fue, según el decir de un respetable órgana [sic] de la Prensa de la Capital, la unánimo [sic] manifestación de aplauso con que se recibió al darle lectura en la Cámara de Representantes, y la franca alegría de todo el que luego ha tenido conocimiento de él, pensando, quizá con razón, que si llega a ser ley de la Republica, habremos dado un paso, en el camino de la verdadera civilización, toda vez que con ella terminaría para nuestro pueblo, esa forma de esclavitud tan odiosa como injusta ${ }^{10}$.

\section{En una de las intervenciones el representante León Gómez expresó:}

Una de las cosas porque más he trabajado en mi vida ha sido por la abolición de la manera salvaje y atroz con que el reclutamiento se practica entre nosotros, cumplo el querer claro y expreso de mis electores, que es además -me atrevo asegurarlo- el de todos los hombres justos de Colombia, al aclamar ahora, una vez más, por la definitiva proscripción de aquella bárbara costumbre; $[\ldots]$ Porque ¿qué otra cosa es nuestro reclutamiento sino una nueva esclavitud de las clases infelices y desheredadas en provecho de los políticos, los revolucionarios y los que ocupan altos puestos? ¿Qué es, entre nosotros, sino una infame y sangrienta cacería de hombres libres, hecha en los albores del siglo XX, idéntica a las de los negros del África Central?

Y además destacaba:

[...] insistimos en enviar partidas de tropa a arrebatar a los labriegos infelices todos sus derechos; a que los traigan amarrados como animales bravíos; a que les roben sus bienes, les destruyan sus labranzas y les violen sus hogares, a que ultimen a balazos a los que tratan de huir en la infame cacería; a traficar con muchos obligándolos a rescatar su libertad mediante la entrega de todos sus ahorros, de sus animales de trabajo o del honor de sus esposas e hijas! He ahí, ciudadanos Representantes, el reclutamiento que se practica entre nosotros y que yo pido que se proscriba y se castigue ${ }^{11}$.

Producto de estas posturas y debates en contra del reclutamiento forzoso (de los cuales también fueron participes los senadores Benjamín Herrera, Aurelio Mutis, Juan N. Valderrama, Carmelo Arango y Rafael Corral) fue la expedición de la Ley 40, sancionada el 26 de octubre de 1909, mediante la cual se establecían los medios para la formación del Ejército en Colombia, con una visión diferente a la concepción militar que predominó en el siglo XIX. En esencia, se buscaba formar y mantener un Ejército a través del sorteo (también conocido como sistema de quinta, el cual

\footnotetext{
10 "Reclutamiento", La Linterna, Tunja, agosto 20 de 1909, pp. 1 y 2. Expresaba el periódico que la abolición del reclutamiento beneficiaria particularmente a Boyacá, debido a que, según informaba, siempre se le exigía a este departamento un contingente de hombres para el ejército mayor que el que se le exigía a los demás, ocasionando daños para actividades como la agricultura, la industria "y aun para la inmoralidad". Sobre el caso de Boyacá y el reclutamiento forzado, donde se puede corroborar lo expresado por La Linterna, se puede consultar el valioso análisis de: Dotor Robayo, María Victoria. "Soldados indios: la 'cuota de sangre' del Estado Soberano de Boyacá en el proceso de formación del Ejército Federal y del Ejército de la Unión Colombiana”, en Historelo, 2012, Medellín.

11 “Abolición del reclutamiento”, El Deber, Málaga, septiembre 18 de 1909, pp. 1 y 2.
} 
consistía en escoger por suerte a los individuos para ingresar a la tropa), el enganche y los reenganches voluntarios ${ }^{12}$. En el art. $1^{\circ}$ se estableció la prohibición de que [...] todo medio que envuelva fuerza o violencia para exigir a los ciudadanos la prestación del servicio militar", mientras que el art. $2^{\circ}$ señalaba que aquellos:

"[...] funcionarios civiles o militares que en cualquier tiempo contravengan a esta prohibición, cometen abuso de autoridad e incurrirán en una multa de cincuenta (50) a doscientos (200) pesos oro, la cual harán efectiva, por denuncio del lesionado o de la persona que lo represente legalmente, los Jueces ordinarios que sean competentes para conocer de los delitos comunes de los empleados o funcionarios públicos. La multa que se imponga le será dada al individuo que haya sufrido la violencia ${ }^{13}$.

La Ley 40 blindaba a los individuos al señalar que aquellos "[...] que sin autoridad o cargo legal forzaren [sic] de cualquier modo a los ciudadanos al servicio militar, sufrirán la pena de dos a cinco años de prisión, previo denuncio del ofendido o de su representante legal"14. Y si bien buscaba el Estado con esta legislación promover el enganche voluntario, los resultados fueron contrarios, lo cual condujo a que el servicio militar se diera de forma obligatoria y, por ende, a que continuara el reclutamiento forzoso, "odioso en todo tiempo", como lo denunciaba un diario de la capital, ya que:

[...] solo van al Ejército individuos que carecen, unos de voluntad para cumplir con los rudos deberes del soldado por la forma en que se les obliga, y otros porque no encontrando modo de ganar el sustento en el trabajo, por incapacidad para ello, aportan todos a la importante institución un no pequeño caudal de vicios y de mala voluntad que, en cambio de levantar la moral de las tropas, la rebajan, minando por completo la disciplina, base principal de toda organización militar ${ }^{15}$.

Posteriormente, se expidió el Decreto n. ${ }^{\circ} 1144$ de 1911 que estableció el servicio militar obligatorio sin que nadie habilitado por la edad, pudiese sustraerse a este deber. El decreto conceptuaba que el servicio militar se había "[...] convertido en los Estados en una necesidad primordial para la defensa nacional"16. Se reconocía que tanto el enganche y reenganche voluntario no habían dado resultado, en parte por "[...] la creciente demanda de brazos para la agricultura y las industrias", lo cual dificultaba el "[...] impulso a la preparación militar del país, por la dificultad para conseguir oportunamente los reemplazos necesarios [...], base indispensable para la efectiva creación del Ejército Nacional". Un duro cuestionamiento fue realizado a este decreto, ya que eximía del servicio a través del rescate por dinero, apartándose de la letra y espíritu de la Ley de $1896^{17}$.

\footnotetext{
${ }^{12}$ Compilación de las disposiciones... Op. Cit., p. 39.

13 "Ley 40 de 1909 por la cual se establecen los medios de la formación del Ejército", en Compilación de las disposiciones... Op. Cit., p. 8.

${ }^{14}$ Ibid.

15 “El servicio militar obligatorio", Pan, Bogotá, junio 12 de 1910, p. 2.

16 “Conceptos del Ministro de Guerra y Decreto n. ${ }^{\circ} 1144$ de 1912 (diciembre 13), por el cual se organiza y reglamenta el servicio militar”, en Compilación de las disposiciones...Op. Cit., p. 37.

${ }^{17}$ Ibíd., pp. 49 y 62. Con el Decreto n. ${ }^{\circ} 1171$ de 1914 se suspendió el pago de exenciones para la prestación
} 
Así las cosas, era apenas comprensible la presencia de un espíritu contrario al servicio militar en amplios sectores de la sociedad. Un espíritu que circulaba entre las personas a través de mecanismos especiales como la música. En un canto de la época, titulado El recluta, se reflejaba en parte la tristeza de quien era obligado a convertirse en soldado:

\author{
El rifle al hombro; la mirada triste; \\ la piel morena; serio el continente, \\ sigue en su marcha al batallón y siente \\ desdén por todo lo que en torno existe. \\ Cuando el cansancio abrumador resiste \\ $\mathrm{y}$ un descenlace trágico presiente, \\ inclina más la pensativa frente \\ y sabe en que la libertad consiste. \\ Ya pasó la refriega [...] Los heridos \\ pueblan de lastimeros alaridos \\ la muda lobreguez de la montaña. \\ Y el ensangue [sic] recluta, en la agonía, \\ desde apartado peñascal envía \\ el último suspiro a su cabaña ${ }^{18}$.
}

Ni siquiera las recomendaciones de las misiones extranjeras contratadas por el Estado colombiano para modernizar el Ejército, encauzaron el servicio militar por senderos capaces de modificar la percepción negativa que de él se tenía. Si bien los chilenos intentaron reglamentarlo, el servicio militar no logró implantarse en la práctica. Los suizos por su parte, entregaron al Ministerio de Guerra varios proyectos sobre distintos tópicos, incluido uno "[...] para hacer más efectivo el servicio militar obligatorio"19, sin obtener mejores resultados.

\title{
Demanda de autoridad $y$ reclutamiento militar en Cundinamarca
}

Desde 1910 el país se encontraba dividido en ocho zonas de operaciones militares. La Primera Zona Militar correspondía a la Región de la 1ra Brigada de Infantería, cuya comandancia se ubicaba en Bogotá. Dicha brigada a su vez estaba dividida en ocho zonas militares: Distrito Militar de Bogotá, n. ${ }^{\circ}$; Distrito Militar de Caqueza, n. ${ }^{\circ}$ 2; Distrito Militar de Fusagasugá, n. ${ }^{\circ}$ 3; Distrito Militar de Girardot, n. ${ }^{\circ}$ 4; Distrito Militar de Facatativá, n. ${ }^{\circ}$ 5; Distrito Militar de Guaduas, n. ${ }^{\circ}$ 6; Distrito Militar de Zipaquirá, n. ${ }^{\circ} 7$; y, Distrito Militar de Guatavita, n. ${ }^{\circ} 8^{20}$.

\footnotetext{
del servicio militar. "El Gobierno actual y la reforma militar", El Tiempo, Bogotá, diciembre 31 de 1915, p. 2.

18 "El recluta", Divisa Roja, Facatativá, noviembre 13 de 1912, p. 2.

${ }^{19}$ Atehortua Cruz, Adolfo León. Construcción del Ejército Nacional... Op. Cit., pp.128 y 148.

20 "Decreto n. ${ }^{\circ} 578$ de 1910, por el cual se organiza el servicio del Escalafón Territorial", en Compilación de las disposiciones... Op. Cit.
} 
En cada Distrito Militar el Comandante debía efectuar el reclutamiento militar, apoyándose en las estadísticas relativas a la población que residía en el respectivo distrito. La permanente demanda de autoridad en las provincias de Cundinamarca explica en parte la promoción del reclutamiento por parte de las autoridades. Al respecto, debe tenerse en cuenta que la Guardia de Cundinamarca era vista como un elemento central para el mantenimiento del orden y la tranquilidad en los pueblos. Muchos prefectos se quejaban de que en su jurisdicción había un déficit de guardias, lo cual no solo debilitaba el ejercicio de su autoridad, sino además significaba que los guardias debían redoblar fuerzas. Las actividades que debían realizar los guardias iban desde la captura de delincuentes, la conducción de presos a lugares fuera de la provincia (por ejemplo, a la colonia de $\operatorname{Acacias}^{21}$ ), la vigilancia de infraestructura, la conservación del orden, entre otras. La cantidad de guardias por provincia variaba de acuerdo a las características de las mismas (extensión, población y desarrollo económico). Por ejemplo, para 1912 y de acuerdo con los datos arrojados por el último censo, en cada provincia debían ser seleccionados para el reclutamiento militar las siguientes personas:

Tabla 1. Selección de personas para el reclutamiento militar de acuerdo a cada provincia.

\begin{tabular}{|c|c|c|c|}
\hline & PROVINCIA & HOMBRES & LE TOCAN* \\
\hline 1 & Bogotá & 162,966 & 130 \\
\hline 2 & Facatativá & 72,924 & 58 \\
\hline 3 & Zipaquirá & 58,866 & 47 \\
\hline 4 & Guaduas & 74,233 & 59 \\
\hline 5 & Ubaté & 50,395 & 40 \\
\hline 6 & Chocontá & 43,960 & 35 \\
\hline 7 & Sumapaz & 29,502 & 24 \\
\hline 8 & Girardot & 21,117 & 16 \\
\hline 9 & Tequendama & 55,914 & 45 \\
\hline 10 & Oriente & 52,651 & 42 \\
\hline 11 & Guatavita & 22,594 & 34 \\
\hline 12 & Guavio & 42,231 & 38 \\
\hline
\end{tabular}

Fuente: Compilación de las disposiciones que reglamentan el servicio militar obligatorio (Bogotá: Imprenta Nacional, 1913), p. 71.

La lectura de las fuentes permite establecer que prácticamente en todas las provincias se necesitaban más guardias de los que había. Por ejemplo, el prefecto de la provincia de Guatavita manifestaba que en su jurisdicción el número de guardias era deficiente, generándose un recargo exorbitante de trabajo para los que se encontraban ubicados

\footnotetext{
${ }^{21}$ Cuando, por ejemplo, los guardias de una provincia debían trasladar presos a dicha colonia, la provincia quedaba sin guardias por varios días. "Informe del Prefecto de la Provincia de Oriente," enero 5 de 1928, en Informe del Secretario... Op. Cit., pp. 186 y 187.
} 
allíi 22 Por otra parte, el prefecto de la provincia de Chocontá solicitaba completar las unidades ya que "[...] fueron retiradas dos parejas y solo quedan cuatro Guardias, que son insuficientes para los distintos servicios que a diario se presentan"23.

En Girardot, capital de la provincia, cuarenta agentes eran los encargados de prestar vigilancia, cantidad que de acuerdo con el prefecto resultaba insuficiente ya que cuando alguno de ellos estaba enfermo, tenían que distribuirse en tres o cuatro turnos para el servicio en la ciudad y en los barrios. Por eso el prefecto reclamaba por lo menos cien agentes para poder atender las diversas actividades, entre ellas la vigilancia de la estación del tren en la ciudad y en Flandes, puertos y bodegas ${ }^{24}$.

Para la provincia de Oriente habían cinco guardias y un sargento, los cuales, en opinión del prefecto, cumplían satisfactoriamente su labor, tales como capturas de sindicados, conducción de presos y hacer guardar orden en las poblaciones en donde se han celebrado ferias u otra clase de actos públicos que traen consigo aglomeración de gente. Sin embargo, el prefecto solicitaba siquiera dos unidades más, ya que los Guardias existentes debían

[...] cumplir no solamente las comisiones enumeradas sino las muy frecuentes de conducción de presos para la colonia de Acacias, en las cuales se ocupa todo el personal y queda, por tanto, desprovista esta ciudad casi siempre por el término de dos días, y esto se repite con mucha frecuencia ${ }^{25}$.

El propio Comandante del Cuerpo de Guardias de Cundinamarca se sumaba a las demandas planteadas por los prefectos, incluyendo, además del aumento de personal, el de los sueldos ${ }^{26}$.

Tabla 2. Total de conscriptos seleccionados en la provincia de Guatavita.

\begin{tabular}{|c|c|}
\hline MUNICIPIO & NUMERO \\
\hline Guatavita & 12 \\
\hline Guasca & 11 \\
\hline Gachancipa & 6 \\
\hline Sopó & 7 \\
\hline Sesquilé & 12 \\
\hline Tocancipá & 9 \\
\hline TOTAL & 57 \\
\hline
\end{tabular}

Fuente: Informe del Prefecto de Guatavita, enero 5 de 1928, p. 101.

\footnotetext{
22 "Informe del Prefecto de Guatavita", enero 5 de 1928, Informe del Secretario... Op. Cit., p. 94.

23 "Informe del Prefecto de la Provincia de Chocontá", diciembre 31 de 1927, Informe del Secretario... Op. Cit., p. 25.

24 "Informe del Prefecto de la Provincia de Girardot, Parte Segunda, enero 5 de 1928", Informe del Secretario... Op. Cit., pp. 137 y 138.

25 "Informe del Prefecto de la Provincia de Oriente, enero 5 de 1928", Informe del Secretario... Op. Cit., pp. 186 y 187.

26 "Informe del Comando del Cuerpo de Guardias de Cundinamarca. Comandante del Cuerpo Carlos Malo B.” febrero 14 de 1928, Informe del Secretario... Op. Cit., p. 15.
} 


\section{Imaginarios sobre el servicio militar}

Un hecho debe ser destacado: la presencia simultánea de dos concepciones antagónicas en torno al reclutamiento militar. Por un lado, una de carácter oficial o institucional, la cual era promovida por el Estado y sus agentes (autoridades), y que advertía de las bondades del servicio militar, al poseer este un conjunto de valores positivos que se divisaban como necesarios tanto para el individuo como para la sociedad. De otro lado, una concepción de la cual eran portadores los individuos del común, y que se alimentaba de temores, dudas y cuestionamientos al reclutamiento, muchos de ellos derivados de situaciones familiares conocidas directa o indirectamente (el rumor jugó un papel destacado en esto), y que fortalecieron las actitudes de rechazo a la conscripción. A continuación se intentará reconstruir aspectos de las dos concepciones para poder comprender la complejidad que acompañó la aplicación del reclutamiento militar forzado en el departamento de Cundinamarca, así como para identificar las formas de reacción que desplegaron las autoridades y los sectores populares, tanto para promoverlo como para evadirlo.

\section{Desde la institucionalidad: un deber sagrado}

Las autoridades militares y civiles fueron portadoras y promotoras de una concepción sobre el servicio militar que lo ligaba a un deber sagrado ${ }^{27}$, que se justificó con el argumento de que antes que acabar con los individuos, como solían creer ciertos sectores de la opinión pública, contribuía a la transformación de los individuos en "verdaderos hombres", que salían de los cuarteles preparados "[...] para las luchas de la vida" ${ }^{28}$. Este tipo de razonamiento, que invocaba la idea de fortaleza física y masculinidad, tenía una larga historia que estaba asociada a la esencia misma del ejercicio militar, y que fue reproducida en Colombia sin el menor cuestionamiento. Por ejemplo, la Misión Chilena que fue contratada por el Estado colombiano para organizar al Ejército a comienzos del siglo XX, reprodujo y afianzó el imaginario que concebía la conscripción como fecundadora del "coraje en los varones"29.

Quien había prestado el servicio militar, decía un promotor de esta política, había sufrido una transformación especial:

Ya no es un simple soldado el que se retira de los cuarteles al terminar su periodo, es un ciudadano, cuya moralidad y probidad reposan en la satisfacción del deber que ha cumplido; lleva en su alma, desarrollando, el amor profundo a la Patria que lo vio nacer, y en su corazón, el recuerdo gratísimo de los meses que se deslizaron en el servicio, donde cosechó un aprendizaje útil y metódico, y en donde dominó sus pasiones y carácter, absorbiendo con placer el amor al trabajo y la actividad necesaria para afrontar las luchas del diario batallar de la vida ${ }^{30}$.

\footnotetext{
${ }^{27}$ Guerrero, Sixto. Apuntamientos sobre la organización y servicio militar obligatorio (Bogotá: Imprenta de El País, 1913), p. 3; "Informe del Prefecto de la Provincia de Zipaquirá", enero 15 de 1928, Informe del Secretario...Op. Cit., p. 293.

28 "Informe del Prefecto de la Provincia de Zipaquirá," enero 15 de 1928, Ibíd.

${ }^{29}$ Atehortua Cruz, Adolfo León. Construcción del Ejército Nacional...Op. Cit., p. 128.

${ }^{30}$ Guerrero, Sixto. Apuntamientos sobre la organización... Op. Cit., p. 11.
} 
Tal concepción fue replicada durante el periodo de estudio, y de manera ininterrumpida, por los oficiales, como lo hizo en 1929 el mayor José J. Mesa, oficial encargado por el Ministerio de Guerra para las labores de reclutamiento en Santander, quien llegó a afirmar que el servicio militar obligatorio era "[...] motivo de varonil orgullo" "31. Aunque también fue reproducida en las provincias por las autoridades locales (lo cual daría cuenta de lo extendido que se encontraba dicho imaginario institucional), hecho que resulta apenas entendible si se comprende que eran estas, en el terreno, las que debían garantizar que se efectuara con éxito el reclutamiento. No obstante el carácter positivo con que se promovía el servicio militar, este debía enfrentarse con múltiples inconvenientes relacionados con situaciones que acompañaban el servicio mismo, y que eran de público conocimiento. A modo de ejemplo, era conocido el efecto negativo de un problema asociado al servicio militar, como la transmisión de enfermedades venéreas en los propios cuarteles ${ }^{32}$. Al respecto, se tenía la idea, muy generalizada, de que el servicio militar servía como mecanismo para la difusión acelerada de este tipo de enfermedades ${ }^{33}$, algo de lo que daba cuenta el prefecto de la Provincia de Ubaté cuando indicaba que las enfermedades:

[...] se propagan principalmente por los conscriptos que regresan infectados a sus hogares después de prestar el servicio militar obligatorio, hace [sic] necesaria la intervención del Gobierno departamental a fin de que antes de licenciar los contingentes se examinen escrupulosamente sus unidades, poniendo tratamiento adecuado a quienes puedan volver a sus hogares a propagar el mal que viene minando nuestra raza hasta el punto de poner en peligro nuestra soberanía en el futuro si no se reglamenta científicamente la prostitución en Colombia ${ }^{34}$.

Otro factor que incidía en contra de la concepción institucional del servicio militar, era la del miedo al Ejército y a los oficiales que lo comandaban. Como está registrado en diversos documentos, en muchos sectores de la población se evidencia un temor al Ejército y, en particular, a los oficiales de distinto rango, por los malos tratos que estos daban a los soldados y conscriptos. En un documento oficial se señalaba que:
Algunos oficiales no quieren comprender que su misma categoría los obliga a ser buenos y juzgan que, por el contrario, el grado los autoriza para dar malos ejemplos, para ser antihumanitarios, para descuidar al conscripto y aún para arrebatarle el pan. Es esta una de las causas del terror al servicio militar y del odio al ejército ${ }^{35}$.

Los malos tratos no se circunscribían solo a las poblaciones de Cundinamarca. En Cúcuta el maltrato físico en los cuarteles incidía en la motivación de los jóvenes para evadir el servicio militar, como se evidencia a continuación:

\footnotetext{
31 "El reclutamiento", Vanguardia Liberal, Bucaramanga, mayo 19 de 1929, p. 4.

${ }^{32}$ Atehortua Cruz, Adolfo León. Construcción del Ejército Nacional... Op. Cit., p. 165.

33 “El servicio militar obligatorio", El Diario Nacional, Bogotá, enero 27 de 1926, p. 3.

34 “Informe del Prefecto de la Provincia de Ubaté, 2 de enero de 1928", Informe del Secretario... Op. Cit., p. 279.

${ }^{35}$ Citado en Atehortua Cruz, Adolfo León. Construcción del Ejército Nacional... Op. Cit., p. 171.
} 
Los jóvenes inscritos a quienes tocó el sorteo en el servicio militar hacen enormes esfuerzos para eximirse [...], con motivo de la malísima alimentación que se les da en los cuarteles y por el malísimo trato que le dan los superiores, especialmente los sargentos, cabos, etc,. porque los tales son peones en su mayor parte que han hecho la siguiente escala; arrieros, soldados rasos y ahora suboficiales, los soldados a quienes se ha dado de baja no encuentran palabras que den una idea de los vejámenes, insultos y atropellos que sufren en el cuartel, especialmente los jóvenes de la sociedad. Con estos últimos, los cabos extreman su agresividad, pues a cada momento dicen: Vamos a fregar a este tipo, que es un filipichín ${ }^{36}$.

La situación derivada del maltrato a que era sometido el conscripto se complicaba por las difíciles condiciones en que aquellos debían cumplir con el servicio militar. La mala alimentación, el pésimo estado de los uniformes y los trabajos extenuantes que debían realizar los conscriptos, alimentaron de modo considerable la precepción negativa del servicio militar obligatorio, como quedó registrado en una nota aparecida en un diario de Bogotá:

He visto con mis propios ojos que en varios de los días de esta semana han subido por la calles de la plaza de mercado dos pobres soldaditos que sobre su uniforme de soldados de la patria y guardianes del honor nacional, llevaban enormes tercios de pasto. Sobre la espalda el pasto y sobre la boina el petral formaban más que un aspecto digno de lástima, desconsolados, porque entendimos que entre el servicio militar y el servicio de caleteros hay una gran diferencia. Ahí están las causas por las cuales la juventud tiene gran terror a los puestos del cuartel ${ }^{37}$.

Es comprensible, por lo anterior, que muchos jóvenes asociaran el servicio obligatorio con la mala fortuna o una especie de castigo ${ }^{38}$.

\section{Desde los conscriptos y sus familias}

Diversas razones fueron esgrimidas por quienes se opusieron al reclutamiento militar (conscriptos, familiares y en diversas ocasiones las propias autoridades locales), como quedó registrado líneas arriba. En verdad, existía una fuerte reacción hacia el servicio militar obligatorio en gran parte de los pueblos e incluso en la propia capital del país. El prefecto de la Provincia de Rionegro se refería a la imposibilidad de que "[...] el pueblo se convenza de la conveniencia de esta institución, para aceptarla de buen agrado; todo el mundo rehúsa esta obligación y hay hacia ella una repugnancia igual a la que produce la imposición de una pena"39.

\footnotetext{
36 “El servicio militar", El Tiempo, Bogotá, enero 11 de 1928, p. 7.

37 "Pobres soldados", El Tiempo, Bogotá, agosto 16 de 1928, p. 5.

${ }^{38}$ Atehortua Cruz, Adolfo León. Construcción del Ejército Nacional... Op. Cit., p. 209.

39 "Informe del Prefecto de la Provincia de Rionegro", enero 10 de 1928, Informe del Secretario... Op. Cit., p. 206.
} 
Imagen 2. Campesinos de los pueblos de la Sabana reclutados por el gobierno para servir en el ejército, 1899.

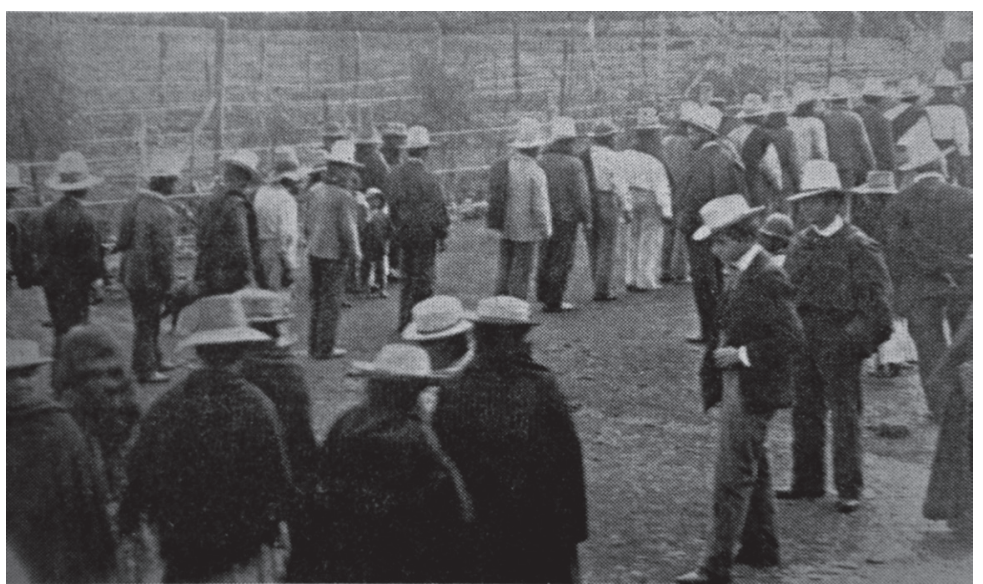

Fuente: Deas, Malcom y Pinzón de Lewis, Patricia. Colombia a través de la fotografia: 1842-2010 (Bogotá: Fundación Mapfre-Taurus, 2011).

Uno de los principales argumentos que esgrimían los sectores populares (particularmente habitantes del campo) era que durante el tiempo de permanencia en el servicio militar, las personas perdían los hábitos para el trabajo y se debilitaban físicamente. Los pobladores de Fosca, por ejemplo, afirmaban que "[...] solo el pobre va a los cuarteles a perder sus hábitos de trabajo, su salud física, pues los soldados vuelven tarados específicamente [sic]" ${ }^{40}$. Esta percepción crítica, en la cual parecía existir una especie de "economía moral" que reivindicaba el bienestar material de los afectados, era muy generalizada en el departamento. Por ejemplo, el prefecto de la provincia de Zipaquirá la identificaba cuando advertía de la existencia de una "[...] infundada creencia que tiene nuestro pueblo de que el servicio militar obligatorio acaba con los individuos"41. El cuartel, así las cosas, era visto como un lugar que transformaba a los jóvenes en sentido negativo, al devolverlos "[...] a sus casas convertidos en seres perezosos e inútiles" ${ }^{42}$, despojándolos de sus habilidades para el trabajo y, en últimas, afectando la economía de los familias. Incluso esta percepción la compartían personas que habían hecho parte del Ejército, como Agustín Mercado, un oficial que tomó cursos en tiempos de la Misión Chilena, quien manifestó en alguna oportunidad que solo se llevaban a "[...] los cuarteles a los hijos del pueblo a degenerarlos y envilecerlos" ${ }^{\prime 3}$. Y desde un diario de Bogotá se estableció que el reclutamiento militar tal y como se llevaba a la práctica, estimulaba la pobreza de la raza en el país ${ }^{44}$.

\footnotetext{
${ }^{40}$ El Diario Nacional (Bogotá), abril 3 de 1929, p. 6. Algo semejante en "Informe del Prefecto de la Provincia de Zipaquirá", enero 15 de 1928, Informe del Secretario... Op. Cit., p. 293.

41 "Informe del Prefecto de la Provincia de Zipaquirá, 15 enero de 1928", Informe del Secretario... Op. Cit., p. 293.

42 "El servicio militar obligatorio", El Disco, Salamina, diciembre 7 de 1912, p. 1.

${ }^{43}$ Citado en Atehortua Cruz, Adolfo León. Construcción del Ejército Nacional... Op. Cit., pp. 185 y 186.

44 "El reclutamiento ha demostrado la pobreza de la raza", El Tiempo, Bogotá, septiembre 12 de 1928, pp. 1 y 2 .
} 
A estas percepciones se sumaban las posturas asumidas por los universitarios, quienes también tenían duras lecturas del servicio militar obligatorio. Por ejemplo, Miguel Ángel Ocampo Patiño, alumno de la facultad de Derecho de la Universidad Libre, señaló, retomando algunas de las tesis que sobre la degeneración de la raza circulaban con fuerza en la época, que el militarismo atrofiaba “ [...] la sociedad mental y moralmente por estar constituido en su mayor parte por individuos amigos de los vicios como son: la embriaguez, el juego, la prostitución, etc.”. Destacaba asimismo que al país le representaba un gasto exagerado la conscripción militar, por lo que planteaba:

[...] que, si en lugar de emplearse en degenerar los caracteres con tan despótica e imbécil instrucción militar, se empleara en la instrucción física e intelectual de la juventud, tendría la patria soldados mejor preparados, de mayores audacias que los harían más arrojados, vigorosos y activos para su defensa en los momentos más peligrosos de caer en guerra con otra nación ${ }^{45}$.

Por último, se debe destacar la existencia de una amplia percepción sobre el servicio militar, tal vez la más importante, que resaltaba su marcado carácter antidemocrático, en la medida en que afectaba solo a los más desválidos que no tenían los recursos económicos y políticos para evadirlo. Se pensaba, en efecto, que el servicio militar era obligatorio "[...] solo para quienes no pueden eximirse de él con las influencias que dan la posición o el dinero"46, es decir, que era prestado por "[...] los infelices y los labriegos que carecen de influencias políticas para librarse del mandato legal, que los ricos o los hijos de los caciques burlan descaradamente" 47 .

En un marco social como el que se ha descrito es comprensible que la angustia de muchos conscriptos en su manifiesto deseo de evadir el servicio militar diera origen a un negocio que fue aprovechado por avezados abogados, quienes interesados en sacar provecho de la situación, según informaba la prensa, "[...] se encargan de gestionar excenciones [sic] del servicio, por precios módicos que van desde dos hasta diez pesos oro"48. Pero además de los tinterillos, presentes en distintos lugares del departamento, también se aprovechaban algunos empleados "[...] que sin pudor han establecido en algunos Municipios un negocio lucrativo con el servicio militar, cobrando fuertes sumas por borrar de la lista de conscriptos a muchos de ellos"49.

\section{Formas de reclutamiento}

El artículo $2^{\circ}$ del Decreto Militar n. ${ }^{\circ} 127$ de 1910 dispuso la presencia en cada Distrito Militar de Comandante responsable de aplicar el Reclutamiento Militar, llevando las estadísticas correspondientes para su ejecución. Los días de inscripción y selección

\footnotetext{
45 "El militarismo en Colombia", El Diario Nacional, Bogotá, junio 10 de 1925, p. 5.

46 "El servicio militar obligatorio", El Tiempo, Bogotá, diciembre 29 de 1915, p. 2.

47 "Por la dignidad del soldado", El Tiempo, Bogotá, junio 8 de 1923, p. 4.

48 "El servicio militar obligatorio", El Tiempo, Bogotá, diciembre 29 de 1915, p. 2.

49 "Informe del Prefecto de la Provincia de Rionegro, enero 10 de 1928", Informe del Secretario... Op. Cit., p. 206. La fuerza de esta interpretación tuvo un momento especial en marzo 13 de 1924, cuando en el Congreso se aprobó una resolución de protesta ante el Gobierno, por el hecho de que el servicio militar obligatorio fuera solamente para los pobres, y se exigió que se hiciera extensivo a los ricos. Torres Giraldo, Ignacio. Los inconformes (Bogotá: Editorial Latina, 1978, t. III), p. 737.
} 
solían ubicarse en los meses de noviembre y diciembre, por lo regular el día de mercado, cuando generalmente había bastante concentración de personas ${ }^{50}$. Los Oficiales de reclutamiento, sobre quienes recaía directamente la responsabilidad de efectuarlo ${ }^{51}$, se apoyaban en los libros parroquiales, para establecer los censos y definir los individuos que cumplían la edad requerida para entrar al sorteo. Por tal motivo, jugaba un papel especial el cura de parroquia en las jornadas de reclutamiento, toda vez que era él el único que tenía información sobre la población, convirtiéndose en determinador, en muchas ocasiones, de las personas que debían estar en el sorteo, ya que en ocasiones "[...] manejaba la información a su amaño, excluía a sus protegidos, y podía ejercer selección política o religiosa sobre la convocatoria", toda vez que "[...] el registro parroquial no podía ser controlado ni observado siquiera por el oficial de reclutamiento y era falta de consideración y respeto dudar de la palabra del cura" ${ }^{\text {2. }}$. En ocasiones, cuando el número de candidatos era mayor a la cantidad de conscriptos requerida, se procedía al sorteo, que, según el art. 19 del Decreto 1144 de 1912, debía hacerse público y cualquier ciudadano podría reclamar de él ante las autoridades. Este mecanismo, como veremos, fue burlado permanentemente a través del fraude y las influencias políticas.

Imagen 3. "El último recluta".

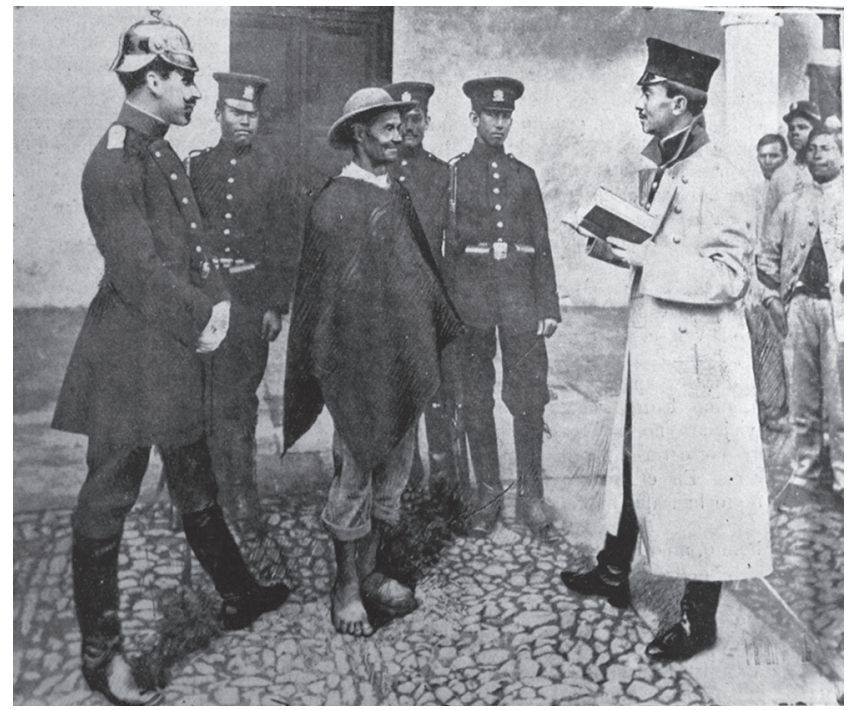

Fuente: El Gráfico, Bogotá, 1912*.

\footnotetext{
${ }^{50}$ Podía ocurrir que en las temporadas de reclutamiento se reclutara a personas que después no resultaban aptas para el servicio militar, como sucedió en 1934 cuando solo Bogotá y algunas poblaciones vecinas fueron reclutados cerca de cuatro mil conscriptos, de los cuales una cifra menor resultó apta. "Reclutamiento", El Heraldo Católico, Chinácota, julio de 1934, p. 4.

${ }^{51}$ En muchas ocasiones por estar sancionados o por estar en desgracia con sus superiores. Cruz, Atehortua y León, Adolfo. Construcción del Ejército Nacional...Op. Cit., pp. 167 y 168.

${ }^{52}$ Ibid.

* El Gráfico comenta la fotografía de la siguiente forma: "Más que una fotografía, esto puede llamarse un cuadro comparativo de dos épocas. Fue tomado [sic] precisamente cuando la ley prohibió el reclutamiento y empezaba a tomar vigor la reforma militar. ¿Qué diferencia entre el voluntario con lazo de ayer y el soldado de hoy. El retratado es el último recluta, a quien leyeron el Código Militar, del cual reía como en tiradera sin entender palabra”.
} 
Generalmente, el Oficial empleaba la fuerza para someter a los conscriptos, y en ocasiones esta era tan desmedida (fue célebre en muchos lugares el uso de la camisa de fique y el garrote), que se señaló que más que las epidemias de los cuarteles, la táctica de infundir pánico en los remisos por medio del garrote era más efectiva ${ }^{53}$. Lo anterior dio pie para que desde las páginas de El Tiempo se denunciara que los conscriptos eran tratados como delincuentes, luego de que se conociera que "[...] en las propias calles y plazas de la capital de la república se redujo a prisión a ciudadanos que no han sido sorteados, ni siquiera figuran en las listas del servicio, por los encargados de llevar contingentes a las unidades del Ejército Nacional" ${ }^{54}$. Hechos como estos dieron origen a actos de violencia en reiteradas ocasiones, que involucraban a conscriptos, familiares, vecinos y guardias ${ }^{55}$.

El uso de la violencia por parte de las autoridades tenía implicaciones para la vida cotidiana de los pobladores. Por ejemplo, en Fosca, la Semana Santa de 1929 se vio afectada, "[...] ya que fue concurrida por muy poco cristiano, por temor a las balas de Novoa", el oficial de reclutamiento ${ }^{56}$. En la población de San Marcos, justo cuando sus habitantes celebraban una fiesta anual, un "piquete" de policías armados irrumpió sembrando alarma y terror, reclutando a once personas, "[...] la mayor parte forasteros, individuos de otras provincias que habían ido con sus negocios a las ferias, y los jóvenes que no llenan requisitos de edad". Los actos obligaron a los campesinos a huir "[...] alarmados al corazón de la montaña, a vivir a la intemperie, exponiendo su salud y la vida", mientras se perdían "[...] los víveres que llevan a la feria, lo que ocasión[ó] una seria alza en el precio de ellos"

Hechos como estos permiten entender por qué El Diario Nacional definió la práctica del reclutamiento en muchos lugares de Cundinamarca como una auténtica "cacería" de jóvenes. En Fosca, los pobladores denunciaron la forma imprudente, torpe y escandalosa como procedieron las autoridades encargadas de recoger a los conscriptos. Los hechos los recogemos en su totalidad para ilustrar la magnitud de los mismos:

El jefe Novoa, [...] hizo rodear la iglesia de gentes armadas, pertenecientes a la guardia de Cundinamarca y al ejército nacional, mientras decaía la misa de Domingo de Ramos, para recoger a quienes estaban adentro, atropellando así los fueros del lugar sagrado y ofendiendo los sentimientos profundamente religiosos de los vecinos. Después, a la salida de la gente, y como no pudieron

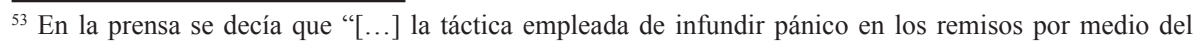
garrote, es más disolvente para el ejercicio que la constante transhumancia de los contingentes, y que las epidemias de los cuarteles". "El reclutamiento", El Tiempo, Bogotá, septiembre 19 de 1928, p. 7.

54 “El reclutamiento", El Tiempo, Bogotá, marzo 30 de 1927, p. 3.

${ }^{55}$ No solo se registraron en Cundinamarca. Por ejemplo, en Mompox la comisión de reclutamiento al mando del Capitán Matías Pinilla, ocasionó hechos dramáticos cuando al pretender realizar el reclutamiento, uno de los soldados de la comisión disparó ante un grupo de personas, causando la muerte de un adulto y heridas a un menor de edad. "Los escándalos del reclutamiento en Bolívar", El Tiempo, Bogotá, septiembre 19 de 1923, p. 1.

56 "Los conscriptos de los campos son recogidos en forma del todo violenta", El Diario Nacional, Bogotá, abril 3 de 1929, p. 6.

57 “De San Marcos”, El Tiempo, Bogotá, agosto 31 de 1923, p. 4.
} 
capturar a todos dispararon sobre un grupo de campesinos, que volvía a sus viviendas de Saname, de cuyo ataque resultó herido el honrado comerciante Miguel Acosta Rozo, muy querido aquí y en Caqueza ${ }^{58}$.

En estas circunstancias era apenas entendible que los vecinos y los familiares de los conscriptos y de los agredidos reaccionaran, en ocasiones también de forma violenta, contra los soldados, dando como resultado que estos fueran maltratados por la guardia, e incluso a que fueran detenidos como ocurrió en la población arriba mencionada:

Por razón de la justa protesta popular que fue el derecho de defensa contra atropellos inauditos, el jefe Novoa redujo a prisión a meritorios padres de familia, ciudadanos ejemplares, como el coronel Manuel J. Baquero R., el patriarca Mesías Agudelo, que lo fue de la protesta redetora [sic] del domingo de ramos, Fidel Moreno, Enrique Clavijo, Lisandro Pardo, Daniel Porrun, varios vecinos de Tanque, todos los cuales están incomunicados en Caqueza sin que por autoridad competente se haya librado boleta de prisión y sin que se les haya recibido indagatoria, ni iniciado sumario ninguno. Denunciamos este hecho ante el procurador y el ministro de gobierno, para que haga cesar esta injusticia ${ }^{59}$.

Desde las páginas de los periódicos se afirmaba que las autoridades civiles y militares se dedicaban " [...] al abuso y atropello contra los ciudadanos de Cundinamarca y de los departamentos, para llevarlos sin razón suficiente a los cuarteles" ${ }^{60}$. Incluso en Bogotá era común que se registraran hechos de este tipo:

La caza de jóvenes, de casi niños y hasta de ancianos, es demasiado común en esta capital, en donde los agentes de la seguridad se encargan de sembrar la inseguridad, de llevar la desolación a los hogares, de arrebatar a pobres padres, a tristes esposas, a pequeños niños el amparo y el consuelo que les proporcionan la presencia y el trabajo de sus hijos, hermanos, esposos y padres, a quienes cazan con saña en las calles, en las oficinas y en los talleres [...]

Destacaba además el diario capitalino la arbitrariedad de la guardia al no respetar lo consignado en la Ley sobre el reclutamiento en los lugares de trabajo:

En el cuartel de ferrocarrileros Mejía hemos visto jóvenes que escasamente habrán cumplido los diez y seis años, jóvenes trabajadores, consuelo y único apoyo de sus familias, arrebatados a las nobles labores del taller, para llevarlos a los cuarteles, ocasionando así a sus familias, particularmente a sus padres el retiro brusco del qué comer. En ese mismo cuartel hemos visto casi ancianos cuya presencia allí denota claramente que quienes los capturan ignoran absolutamente la misión que se les ha encomendado, pareciendo más que otra cosa, un nuevo sistema de persecución. Nos gustaría saber, para hacerla conocer ampliamente, cuál es la disposición por la cual puede la policía de seguridad

\footnotetext{
58 "Los conscriptos de los campos son recogidos en forma del todo violenta", El Diario Nacional, Bogotá, abril 3 de 1929, p. 6.

${ }^{59}$ Ibid.

60 “El reclutamiento”, El Diario Nacional, Bogotá, mayo 4 de 1929, p. 3.
} 
dedicarse a cazar a los varones a quienes nunca se les ha hecho notificación alguna respecto a servicio militar obligatorio ${ }^{61}$.

La arbitrariedad de los oficiales de reclutamiento se reforzaba con la que mostraban los alcaldes, quienes sacando ventaja de su posición en el plano local, incidían en la suerte de los conscriptos por motivos de orden político o económico. Para destacar algunos casos, se puede referir lo que le sucedió a Jorge Sandoval, quien debió reemplazar en la lista de escogidos a Evangelista Celis, protegido por el alcalde de Anolaima, por ser de familia acomodada. O lo que le ocurrió a Rafael Gantiva, oriundo de Pandi, a quien le tocó prestar el servicio, siendo suplente, ya que el principal "[...] hizo negocio con el alcalde para que no lo obligara a prestar servicio". O a Eliecer Gómez de Pacho, a quien el alcalde le notificó que debía prestar el servicio militar, sin que se hubiesen fijado las listas de los que debían ser sorteados. En fin, podrían, mencionarse muchos casos similares a estos ${ }^{62}$, registrados a lo largo del periodo de estudio. En 1927, por ejemplo, el diario El Tiempo dio cuenta de las arbitrariedades del alcalde de Pacho, al momento de llegar el sorteo:

Con motivo de la provisión para el contingente del servicio militar obligatorio han comenzado a llegarnos las innumerables quejas de todos los años sobre las múltiples arbitrariedades que cometen las autoridades so pretexto de cumplir disposiciones emanadas de los altos poderes públicos. El alcalde de Pacho parece que ha querido incidir esta era, pues al efecto ayer se acercó a nuestras oficinas el señor Muñoz a manifestarnos que la señora del alcalde para con su familia lo había llevado hasta el extremo de incluirle un hijo que no cuenta con la edad legal y otro que por ser estudiante de segundo año de medicina, está claramente excluido. No ha atendido ninguna razón en contra y antes bien resolvió cercar con guardias la casa de la familia Muñoz con el empeño de hacer citar al estudiante referido ${ }^{63}$.

El "sarcasmo del sorteo", como fue denominada la manoseada práctica del mismo por parte de las autoridades, tenía proyecciones nacionales. En Buga, precisamente, se expresaron sus habitantes en esos términos, luego de que al verificarse el sorteo, el alcalde de la ciudad recibiera un telegrama del ministro de Guerra Ignacio Rengifo, en el cual le ordenaba exceptuar del servicio militar a ciertos jóvenes que acudieron a políticos influyentes para librarse de él ${ }^{64}$.

También se manifestaron en contra del reclutamiento los propietarios de negocios que empleaban a trabajadores, ya que estos eran sacados de sus lugares de trabajo

\footnotetext{
${ }^{61}$ Ibid.

62 "Memoria del Comando de la $1^{\text {a }}$ División correspondiente al año 1913", en Compilación de las disposiciones... Op. Cit., p. 128.

63 "El servicio militar y las arbitrariedades", El Tiempo, Bogotá, febrero 13 de 1927, p. 11. El viacrucis vivido por el joven Carlos Alberto Magne por el abuso de autoridad en la aplicación del sorteo para el reclutamiento, recrea el caso de cientos de jóvenes de Cundinamarca y el país, que fueron objetos de todo tipo de arbitrariedades para obligarlos a vincularse al Ejército, pese a que estaban inhabilitados por los mismos mecanismos establecidos por la Ley (por ejemplo, el sorteo). Ver su caso en "Horrible atropello", El Socialista, Bogotá, agosto 4 de 1920, p. 2.

64 “El sarcasmo del sorteo", El Tiempo, Bogotá, septiembre 12 de 1928, p. 7.
} 
y llevados a los cuarteles, afectando los niveles de producción de las empresas o negocios. Un caso registrado en Bogotá permite establecer esto último:

Los señores Rafael Mendoza B. y Pedro Arnulfo Ortiz, empresarios de la fábrica de chinelas y algargatas [sic] santandereanos, que funciona en la carrera quince, número 3-b, se presentaron ayer a nuestras oficinas a quejarse de que en el periodo de la tarde se presentaron en los talleres de la fábrica un Sargento y un Cabo pertenecientes al reclutamiento, y sin más preámbulos sacaron a los obreros que allí estaban trabajando, sin contar con nadie y solamente dejando dos encargados de custodiar la fábrica. Todos estos obreros son traídos desde Santander y la fábrica, que se ha quedado absolutamente sin personal, tendrá que cerrarse mañana, causando a sus propietarios perjuicios incalculables, debido a que no será posible atender a los compromisos que tienen adquiridos en debida oportunidad ${ }^{65}$.

En Une, población cercana a la capital, se registraban hechos que afectaban la producción agropecuaria. Los campesinos, al saber de la presencia del oficial de reclutamiento, huían abandonando la producción:

Con este motivo, todos los campesinos se hallan alarmados y huyen por los montes, por lo cual, de hoy en adelante, se nos dificultarán de una manera palpable, los trabajos de agricultura toda vez que los brazos con los cuales contábamos para dichas labores se nos han ausentado, presentándose con esto un problema grave que solo la cordura del gobierno podría remediarlo ${ }^{66}$.

Desde la región del Sumapaz, Ismael Silva denunciaba que en la Hacienda el Chocho habían sido reclutados todos los trabajadores de las trilladoras, justo cuando había "[...] varias miles de cargas de café en espera de la trilla" ${ }^{67}$.

En otros lugares del país ocurría lo mismo. En Cartagena se cuestionaban los atropellos derivados del reclutamiento forzoso, y la empresa encargada del mantenimiento del ferrocarril en la ciudad se quejaba de que sus empleados fueran sacados violentamente de sus puestos de trabajo, sabiendo de antemano que el contrato con el Estado los eximía del servicio militar ${ }^{68}$. También en la población de Ciénaga el reclutamiento de conscriptos revistió caracteres de escandaloso atropello:

No se tienen en cuenta las disposiciones vigentes sobre servicio militar obligatorio, sino que a los pobres trabajadores se les saca de sus talleres o fincas y se les conduce con la fuerza armada hasta los cuarteles o cárceles. En la región bananera es peor todavía este pavoroso estado de cosas. En Sevilla,

\footnotetext{
65 “Los abusos del reclutamiento", El Tiempo, Bogotá, marzo 20 de 1927, p. 5.

66 "Se siembra el terror con el decreto sobre servicio militar y obligatorio", El Diario Nacional, Bogotá, marzo 31 de 1929, p. 6.

67 "Los trabajadores y el reclutamiento", El Tiempo, Bogotá, abril 2 de 1934, p. 5. El mismo Ismael Silva, dueño de tierras en la región de Sumapaz, había propuesto desde las páginas de los diarios liberales, crear una especie de servicio agrícola obligatorio que debía "[...] prestarse seguidamente al militar, reduciendo este a la mitad, y por un periodo no menor de seis meses". "Estaciones experimentales y servicio agrario obligatorio", La Patria, Bogotá, octubre 29 de 1930, p. 7.

68 "Los atropellos del reclutamiento", El Tiempo, Bogotá, marzo 20 de 1927, p. 7.
} 
en la noche del viernes, un sargento encargado del reclutamiento golpeó con su rifle a un peón de nombre José María Ramos, causándole una grave herida en la cabeza. La infeliz víctima fue a pagar en la cárcel, por orden del Inspector Luis Roberto Campo, la falta de haber soportado pacientemente tamaña ofensa. El mismo sargento, en compañía de algunos soldados, se dio a la tarea de perseguir al honrado artesano señor Jacobo Henríquez, a quien hicieron varios disparos, que por fortuna no dieron en el blanco. Este sistema de reclutamiento, en abierta pugna con elementales deberes de orden legal y de humanidad, quizá no sea del conocimiento del actual Ministro de Guerra, quien seguramente dictara serias medidas que eviten en lo sucesivo estos inmorales atropellos, que hace azarosa la vida en estos lugares ${ }^{69}$.

\section{Formas de evasión de los conscriptos}

A continuación se describirán tres acciones a las que solían acudir los conscriptos que pretendían evadir el reclutamiento: la ausencia el día del sorteo, la huida inesperada y la resistencia violenta y el suicidio.

\section{Ausencia el día del sorteo}

Era común que los opcionados para el reclutamiento no se presentaran el día en que debía efectuarse el sorteo. De acuerdo con las disposiciones oficiales, los dos últimos meses de cada año debían inscribirse las personas que, según la Ley, tenían que cumplir con el deber de prestar su servicio. Sin embargo, al llegar el día del sorteo, no se presentaban en el lugar respectivo, generando una situación incómoda para el oficial de reclutamiento y las autoridades civiles. Incluso, sucedía que tan pronto se conocían las listas de los opcionados, estos huían a poblaciones distantes para evadir la Ley, como sucedió en la provincia de El Guavio ${ }^{70}$. Así, cuando llegaba el día del sorteo, muchos de los candidatos al reclutamiento hacía rato habían dejado de vivir temporalmente en aquel lugar.

Sin duda, se trataba de una acción premeditada de los opcionados (y secundada sin reparos por su familia), motivada por las lecturas negativas que tenían del reclutamiento, las cuales circulaban con asiduidad en distintos escenarios de la vida social. Sobre esto el prefecto de la provincia de Sumapaz advertía en 1928 que:

[...] muchos de los que aparecen en dichos registros y que no tienen causal alguna que les impida evadirse, emigran a otras partes para eludir el cumplimiento de este sagrado deber, y de ahí la dificultad en que se encuentran las autoridades de poder tener al Oficial de reclutamiento el número suficiente de donde poder hacer un sorteo justo y equitativo, dando por resultado que casi

\footnotetext{
69 "De Ciénaga", El Tiempo, Bogotá, octubre 27 de 1922, p. 4.

70 "Informe del Prefecto de la Provincia de El Guavio", enero 15 de 1928, Informe del Secretario...Op. Cit., p. 53.
} 
siempre no se lleva el número que corresponde, ni entre los más los mejores como debiera hacerse ${ }^{71}$.

El prefecto de la provincia de Guaduas daba cuenta de lo difícil que resultaba reunir a los seleccionados, debido en gran parte a que estos contaban generalmente con la ayuda de sus familiares para permanecer ocultos:

El problema en esta materia lo constituye el obtener después de publicado el censo, la comparecencia de los inscritos en él ante el respectivo alcalde para los efectos de la fianza que garantice la presentación al examen de aptitud y la presencia en la cabecera del Municipio el día del sorteo, pues puede garantizarse que más de la mitad de los inscritos no residen en el lugar de su nacimiento, y se ignora en donde puedan ser hallados, con la circunstancia de que los parientes o relacionados casi nunca manifiestan en donde pueda encontrarse el individuo aun cuando lo sepan, hecho que determina para el Alcalde la tarea de investigar por medio del telégrafo con los Alcaldes circunvecinos por la residencia de individuos de quienes casi con rarísima excepción llega a obtenerse dato ${ }^{72}$.

La situación desde luego obligó a las autoridades a tomar medidas al respecto. El prefecto de Guaduas planteó en enero de 1926 una salida:

[...] insinuar la medida que la mayor parte de los países que tienen el servicio militar obligatorio en cuanto a las personas que cambian de domicilio, a quienes se les impone la obligación de hacer la declaratoria de residencia después de transcurrido cierto número de días en cada Municipio, de lo cual se llevaría un registro en la Alcaldía, declaratoria que debe hacerse bien por el padre de familia, o por el individuo, según el caso, bajo sanciones severas por falta de cumplimiento, avisando al Alcalde que reciba la declaración de residencia al del lugar de nacimiento; por este medio, llevando los registros cuidadosamente en las Alcaldías, la autoridad del lugar de nacimiento queda capacitada para saber en qué Municipio residen quienes figuran en el censo, y así si es muy fácil dirigirse a determinado lugar exigiendo la presentación ${ }^{73}$.

Por su parte, el prefecto de la provincia de El Guavio adoptó medidas de fuerza para hacer valer la Ley, informando a las autoridades de Medina (considerado un lugar de paso de quienes, en su afán de evadir el servicio militar, se dirigían hacia los Llanos Orientales), para que capturara a los conscriptos ${ }^{74}$.

\footnotetext{
71 "Informe del Prefecto de la Provincia de Sumapaz", enero 14 de 1928, Informe del Secretario... Op. Cit., p. 227.

72 "Informe del Prefecto de la Provincia de Guaduas", enero 5 de 1928, Informe del Secretario... Op. Cit., p. 169.

${ }^{73}$ Ibid., p. 170.

${ }^{74}$ Ver "Informe del Prefecto de la Provincia de El Guavio", enero 15 de 1928, Informe del Secretario... Op. Cit., p. 53.
} 
Imagen 4. Libreta de servicio.

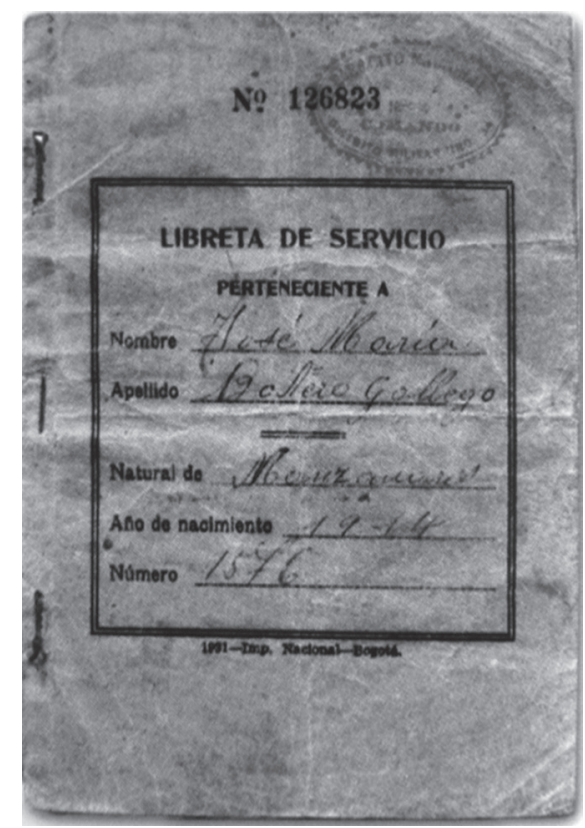

Fuente: Hernández Niño, Nicéforo. Evolución histórica del Servicio de Reclutamiento... Op. Cit., p. 217.

\section{La huida inesperada}

Uno de los mecanismos empleado con mayor regularidad por los conscriptos fue la huida inesperada al notar la presencia de los guardias de reclutamiento, quienes con su sola presencia lograban desatar grandes temores entre la poblacion ${ }^{75}$. En esto jugaban papel determinante recursos como la alerta temprana que circulaba entre los pobladores, y que llegaba pronto a oídos de los afectados, quienes podían así evadir las comisiones de reclutamiento. Incluso el rumor también servía como mecanismo de prevención. Solía ocurrir entonces que los conscriptos se escondían durante varios días en lugares que les garantizaban la tranquilidad de no ser encontrados, mientras pasaba la comisión efectuando el reclutamiento. En ocasiones no solo huía el conscripto, sino que lo hacía toda la familia de este, tal y como sucedía en tiempos de la Guerra de los Mil Días, cuando estas “[...] dejaban sus hogares, llevando a menudo consigo utensilios y animales, y se refugiaban en los montes cercanos" ${ }^{\text {"76. }}$.

\footnotetext{
${ }_{75}$ Que la huida era una práctica de vieja data lo demuestra la anécdota contada por el estadounidense Isaac F. Holton, quien en su correría por el Sumapaz en 1857, contrató los servicios de un joven, quien le manifestó al extranjero su molestia por "[...] no haber ido vestido con su uniforme militar para que yo viera cómo la gente corría a esconderse en el monte pensando que era un oficial de reclutamiento". Velandia, Roberto. Una mirada en el tiempo al paisaje del Alto Sumapaz. Compilación de crónicas de viajeros colombianos y extranjeros (Bogotá: Corporación Autónoma Regional, 1998), p. 71.

${ }^{76}$ Bergquist, Charles. Café y conflicto... Op. Cit., p. 211. Al respecto, señala Fernando López Alves que en algunos países latinoamericanos "[...] se llegaba a tomar como rehenes a las familias de quienes habían sido reclutados por la fuerza, para garantizar su permanencia en el servicio". Ver López Alves, Fernando. La formación del Estado y la democracia en América Latina (Bogotá: Editorial Norma, 2003), p. 64.
} 
La práctica constante de este recurso también ocasionó serios problemas a los responsables del reclutamiento ${ }^{77}$. En la provincia de Zipaquirá, las reiteradas huidas pusieron en dificultades al oficial de reclutamiento:

Como siempre sucede, cuando se presenta el Oficial de reclutamiento, la mayoría de los conscriptos tratan de huir para evadirse de prestar el servicio obligatorio. Sin duda alguna esto obedece a la infundada creencia que tiene nuestro pueblo de que el servicio militar obligatorio acaba con los individuos, cuando antes bien, los convierte en verdaderos hombres, instruye a los analfabetos y los prepara para las luchas de la vida. Por estos motivos la autoridad siempre tropieza con grandes dificultades para obligar a los ciudadanos aptos a que cumplan con este deber sagrado ${ }^{78}$.

\section{Resistencia y suicidio}

Otro recurso empleado para evadir el servicio militar obligatorio fue el enfrentamiento directo de los conscriptos con los miembros de la guardia de Cundinamarca, para impedir ya fuese su presencia en el sorteo, el traslado o la captura del seleccionado. Se trataba, desde luego, de un recurso delicado e imprevisible en sus consecuencias, ya que podía arrojar resultados lamentables, (desde heridos hasta muertos), o incluso levantamientos de pueblos enteros para oponerse a la realización del reclutamiento ${ }^{79}$.

La resistencia violenta también se registraba en contextos diferentes al de Cundinamarca, y en las ocasiones en que se presentaba participaban personas, generalmente familiares, cercanas al joven que debía ser incorporado. Armando Solano recuerda que siendo niño presenció en Paipa un hecho violento en torno al reclutamiento:

En un día de mercado, irrumpió un pelotón de soldados y procedió a reclutar violentamente a los muchachos que estaban en la plaza. Y entonces, sin el menor acuerdo y sin vacilación, las mujeres que vendían se arrojaron sobre la tropa. En breves momentos de una lucha furiosa, los desarmaron y los encerraron en la cárcel. Recuerdo especialmente la intervención de un gremio, el de las vendedoras de sal, que con los terrones de su mercancía apedreaban a los soldados y los descalabraban aparatosamente ${ }^{80}$.

Finalmente, un último recurso para quien pretendía evadir el servicio militar lo constituía el suicidio. No era desde luego el recurso más frecuente, ni el más fácil de ejecutar, pero solían de vez en cuando registrarse casos en Cundinamarca y en otros departamentos, en donde el conscripto tomaba una medida radical, con tal de no ser llevado a la fuerza al

\footnotetext{
${ }^{77}$ Algo parecido sucedió en el marco de la Guerra de los Mil Días, cuando los funcionarios del gobierno se vieron en apuros debido a las reiteradas evasiones, teniendo "[...] dificultades para conseguir más reclutas debido a las precauciones que tomaba el pueblo". Berquist, Charles. Café y conflicto en Colombia (18861910)... Op. Cit., p. 211.

78 "Informe del Prefecto de la Provincia de Zipaquirá, enero 15 de 1928", en Informe del Secretario... Op. Cit., p. 293. Cursiva nuestra.

79 "Servicio militar obligatorio", El Disco, Salamina, diciembre 7 de 1912, p. 1.

${ }^{80}$ Solano, Armando. Paipa mi pueblo y otros ensayos (Bogotá: Banco de la República, 1983), p. 202.
} 
cuartel. Por ejemplo, un tal Juan Rodríguez, de Chaparral, decidió ingerir veneno “[...] para eximirse de quedar bajo el servicio militar obligatorio", no sin antes dejar una carta en donde según se indicó, “[...] para evitar las torturas del cuartel, prefirió la muerte" En otro caso, bien entrado el siglo XX, la práctica del suicidio continuó siendo una opción, como se puede advertir al conocerse el caso de un soldado que se suicidó en el Salto del Tequendama, luego de haber desertado del ejército ${ }^{82}$.

\section{Conclusión}

Christopher Abel afirma que para finales de la década de 1920 Colombia poseía el Ejército Nacional más pequeño en proporción a su población en Suramérica ${ }^{83}$. "Entre 1909 y 1926 -afirma Abel- el ejército conservó un tamaño constante entre 5.000 y 6.000 oficiales y soldados", y no gozó de buenas posibilidades presupuestarias, salvo en la coyuntura de los años veinte, cuando se dio la expansión económica ${ }^{84}$.

La precaria situación del Ejército incidió en la condición y calidad de los reclutas escogidos para el servicio militar. Ello ayuda a entender, en parte, la forma como fue vista la política de reclutamiento en sectores de la población de Cundinamarca y del país, como ya lo mostramos. Una política que por cierto fue objeto de replanteamientos e intentos de reforma en distintos momentos del siglo XIX y primeras décadas del XX. Como afirma Atehortúa Cruz, hasta 1930, “[...] el servicio militar se hallaba al auxilio de la policía o abandonado entre los quehaceres menos importantes del ejército" ${ }^{85}$. Y si bien bajo la administración de Olaya Herrera se reglamentó el servicio militar, prohibiendo el desempeño de empleo público a quien no presentara la libreta militar, y creando nuevas normas para el reclutamiento, no se logró avanzar como se esperaba. En parte, el país se vio sorprendido por el conflicto con el Perú, al no haberse operado una reforma profunda sobre el servicio militar obligatorio.

El fracaso de la Reforma al Servicio Militar Obligatorio se debió, entre otras razones, a los obstáculos promovidos por diversos actores (grandes propietarios, gamonales y curas), quienes "[...] impidieron desde sus localidades la vigencia de un servicio militar obligatorio legislado a medias e inaplicable en la práctica concreta", haciendo que el reclutamiento siguiera “[...] ejercitándose sobre la población paupérrima de las zonas más partidizadas o como sistema local de vindicta" $"$. Por tal motivo, entrada la década de 1930, la práctica del reclutamiento continuó generando temores en la población y reproduciendo arbitrariedades económicas y políticas. Por ejemplo, en ciertos lugares del departamento los campesinos vivían asustados por la práctica de

\footnotetext{
81 "Se suicida para no prestar servicio militar", El Tiempo, Bogotá, agosto 30 de 1928, p. 7.

82 "Un soldadito desertó ayer y se suicidó en el Tequendama", El Tiempo, Bogotá, febrero 8 de 1944.

${ }^{83}$ Abel, Christopher. Politica, iglesia y partidos en Colombia (Bogotá: Universidad Nacional de Colombia, 1987), p. 23.

${ }^{84}$ Ibid., pp. 62 y 63.

${ }^{85}$ Adolfo León. Construcción del Ejército Nacional...Op. Cit., pp. 167 y 168.

${ }^{86}$ Ibid., p. 195.
} 
la "escogida"87, como en Pasca, donde la política partidista determinaba a quiénes se debía reclutar, como se denunció en esta nota:

Con el pretexto de llevar a efecto el reclutamiento de ley, el ex secretario conservador de la alcaldía, en asocio de varias parejas de la Guardia Civil, se trasladó a los campos y cargó con cinco campesinos, quienes se encontraban sobre el surco trabajando la tierra. Los reclutados no son aptos para el servicio militar, cuestión comprobada, pero la medida se consumó. No se ha podido comprobar por qué razón este personaje sombrío comandaba la Guardia Civil, pues no tiene cargo alguno oficial ${ }^{88}$.

Sin embargo, es de advertir un hecho que vino de la mano del nacionalismo que despertó en el país el conflicto con el Perú. Nos referimos al cambio de actitud en torno al "ser soldado de la patria" que, de un momento a otro, llevó a que sectores del país y de Cundinamarca dejaran a un lado las percepciones negativas que tenían del servicio militar, y manifestaran su deseo de vincularse al ejército, para contribuir a la defensa del territorio nacional. Un sentimiento nacionalista arropó a Colombia, y la prestación del servicio militar se convirtió para muchos jóvenes en el camino expedito para demostrar su amor al país. Los universitarios, por ejemplo, antiguos críticos del reclutamiento, manifestaron abiertamente su deseo de vincularse al ejército para defender los intereses nacionales ${ }^{89}$.

Imagen 5. Jóvenes voluntarios para la Guerra con Perú

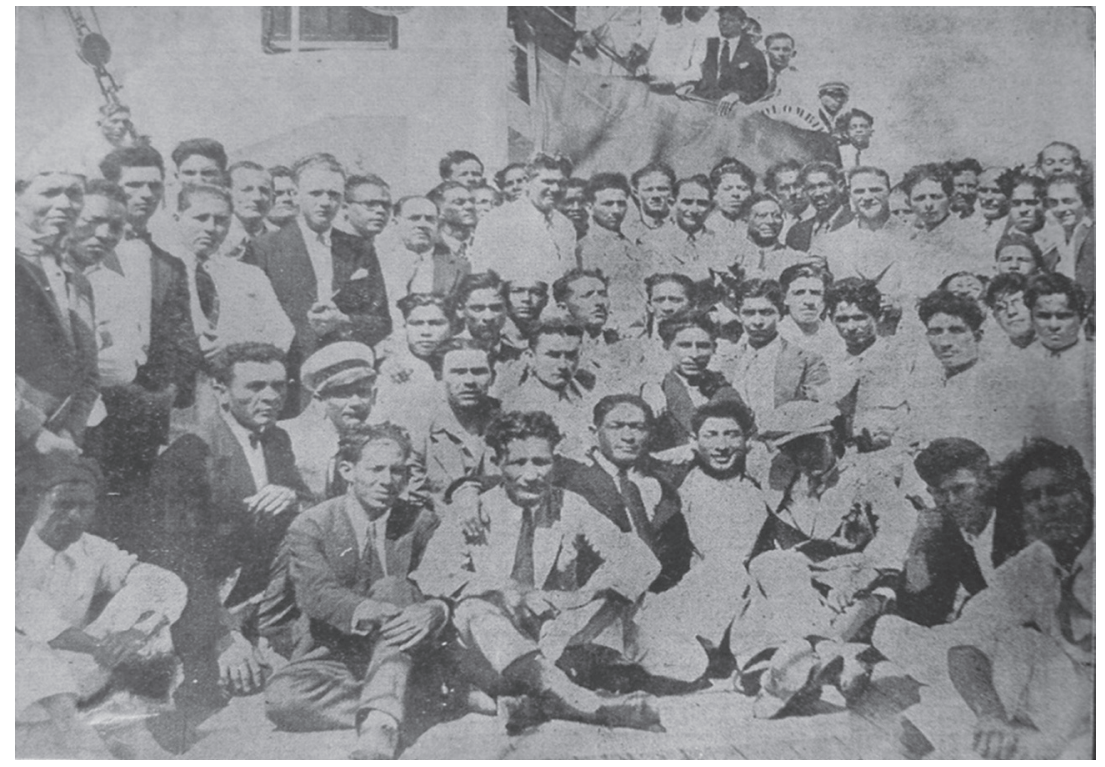

Fuente: Mundo al Día, febrero 15 de 1933, p. 11.

\footnotetext{
87 "Había extralimitación en reclutamiento por parte de la policía", El Bien Social, Bogotá, abril 22 de 1934, p. 4.

88 "En Pasca se atropella a los campesinos", Unirismo, Bogotá, marzo 14 de 1935, p. 7.

89 "Los universitarios quieren ir a la guerra", Mundo al Día, Bogotá, octubre 4 de 1932, p. 12.
} 
Desde luego, fue un breve sentimiento, como breve fue la guerra. Luego de superada la refriega armada y pasados los vientos nacionalistas que la acompañaron, el servicio militar obligatorio como institución, volvió a ser visto como una práctica selectiva, perjudicial y antidemocrática, tal y como había sido concebida antes del conflicto con el Perú en 1932. Una práctica capaz de despertar sentimientos de rechazo, como se observa en un villancico que en forma de plegaria circuló a través de la prensa:

$$
\begin{gathered}
\text { Por el santo pecho que te ha } \\
\text { amamantado } \\
\text { ¡Dulce Jesús que estás dormido! } \\
\text { Te pido } \\
\text { Que este hijo mío no sea soldado } \\
\text { Se lo llevarán } \\
\text { ¡Y era carne mía! } \\
\text { Me lo matarán } \\
\text { ¡Y era mi alegría! } \\
\text { Cuando este muriendo, } \\
\text { dirá: ¡Madre mía! } \\
\text { Y yo no sabré la hora ni el día... } \\
\text { Por el santo pecho que te ha } \\
\text { amamantado } \\
\text { ¡Dulce Jesús, que estás dormido! } \\
\text { Te pido Que este hijo mí no sea soldado }{ }^{90} \text {. }
\end{gathered}
$$

\section{Fuentes}

\section{Fuentes primarias}

\section{Legislación}

Decreto . $^{\circ} 578$ de 1910, por el cual se organiza el servicio del Escalafón Territorial.

Ley 167 de 1896 que organiza el Servicio Militar Obligatorio.

Ley 40 de 1909 por la cual se establecen los medios de la formación del Ejército.

Servicio Militar Obligatorio. Conceptos del Ministerio de Gobierno y Decreto n. ${ }^{\circ}$ 1144 de 1911 (diciembre 13), por el cual se organiza y reglamenta el servicio militar, Imprenta Nacional, Bogotá, 1911.

\section{Informes y documentos oficiales}

Compilación de las disposiciones que reglamentan el servicio militar obligatorio, Bogotá: Imprenta Nacional, 1915.

\footnotetext{
${ }^{90}$ El Bien Social, Bogotá, enero 15 de 1933, p. 4.
} 
Informe del Comando del Cuerpo de Guardias de Cundinamarca, Comandante del Cuerpo Carlos Malo B. Febrero 14 de 1928, en Informe del Secretario de Gobierno al Sr. Gobernador del Departamento. Bogotá: Imprenta del Departamento, 1928.

Informe del Secretario de Gobierno al Sr. Gobernador del Departamento. Bogotá: Imprenta del Departamento, 1928.

"Memoria del Comando de la 1' División correspondiente al año 1913", en Compilación de las disposiciones que reglamentan el servicio militar obligatorio. Bogotá: Imprenta Nacional, 1915.

Sixto Guerrero, Apuntamientos sobre la organización y servicio militar obligatorio. Bogotá: Imprenta de El País, 1913.

\section{Publicaciones periódicas}

Divisa Roja, Facatativá, 1912

El Bien Social, Bogotá, 1930, 1933

El Deber, Málaga, 1909

El Diario Nacional, Bogotá, 1925, 1929

El Disco, Salamina, 1912

El Heraldo Católico, Chinácota, 1934

El Socialista, Bogotá, 1920

El Siglo, Bogotá, 1944

El Tiempo, Bogotá, 1915, 1923, 1927, 1928, 1930

La Linterna, Tunja, 1909

La Patria, Bogotá, 1930

Mundo al Día, Bogotá, 1932, 1933

Pan, Bogotá, 1910

Unirismo, Bogotá, 1935

Vanguardia Liberal, Bucaramanga, 1929 


\section{Fuentes secundarias}

\section{Libros}

Abel, Christopher. Politica, iglesia y partidos en Colombia. Bogotá: Universidad Nacional de Colombia, 1987.

Atehortúa, Adolfo. Construcción del Ejército Nacional en Colombia, 1907-1930. Reforma militar y misiones extranjeras. Medellín: La Carreta Histórica, 2009.

Berquist, Charles. Café y conflicto en Colombia (1886-1910). La Guerra de los Mil Días, sus antecedentes y consecuencias. Medellín: Banco de la República, El Ancora Editores, 1999.

Deas, Malcom y Pinzón de Lewis, Patricia. Colombia a través de la fotografía: 18422010. Bogotá: Fundación Mapfre-Taurus, 2011.

Hernández Niño, Nicéforo. Evolución histórica del Servicio de Reclutamiento y Control Reservas del Ejército Nacional: 1810-2010. Bogotá: Ejército Nacional, 2010.

López-Alves, Fernando. La formación del Estado y la democracia en América Latina. Bogotá: Editorial Norma, 2003.

Martínez Garnica, Armando. Historia de la Guardia Colombiana. Bucaramanga: Universidad Industrial de Cundinamarca, 2012.

Perico García, Jenaro. El maestro Luis A. Calvo. Bucaramanga: Editorial Salesiana, 1975.

Rothlisberger, Ernest. El Dorado. Bogotá: Instituto Colombiano de Cultura, 1993.

Solano, Armando. Paipa mi pueblo y otros ensayos. Bogotá: Banco de la República, 1983.

Torres del Río, César y Rodríguez Hernández, Saúl (eds.). De milicias reales a militares contrainsurgentes. La institución militar en Colombia del siglo XVIII al XXI. Bogotá: Editorial Pontificia Universidad Javeriana, 2008.

Torres Giraldo, Ignacio. Los inconformes. Historia de la Rebeldía de las Masas en Colombia. Bogotá: Editorial Latina, 1978.

Velandia, Roberto. Una mirada en el tiempo al paisaje del Alto Sumapaz. Compilación de crónicas de viajeros colombianos y extranjeros. Bogotá: Corporación Autónoma Regional, 1998. 


\section{Capítulos de libros}

Rodríguez Hernández, Saúl. “¡Aquí comienza la excelencia! Apuntes sobre conscripción y democracia en la Colombia contemporánea”, en Torres del Río, César y Rodríguez Hernández, Saúl (eds.), De milicias reales a militares contrainsurgentes. La institución militar en Colombia del siglo XVIII al XXI. Bogotá: Editorial Pontificia Universidad Javeriana, 2008.

\section{Artículos en revistas}

Dotor Robayo, María Victoria. "Soldados indios: la cuota de sangre del Estado Soberano de Boyacá en el proceso de formación del Ejército Federal y del Ejército de la Unión Colombiana”, en Historelo, 2012. 